\section{A Bite of the Apple. A Life with Books, Writers and Virago \\ Lennie Goodings}

Oxford University Press, 2020, HB, 320pp

£16.99, 978-0198828754

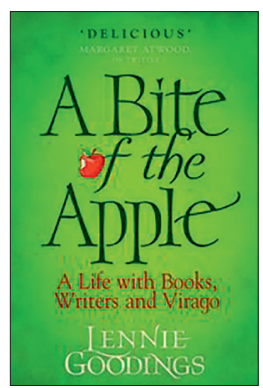

\section{TRAILBLAZERS}

Anyone who loves books will really love this one. It is a celebration of writing, of publishing, and of reading written by someone, Lennie Goodings, who has worked for Virago for over 40 years. Now Virago's chair, when she got her first job as a publicist there she knew that she had found a home ... where books, ideas, politics, imagination, feminism, and business was the air we breathed.' When, shortly after joining, she asked Carmen Callil, who had started the company, why she had done so, the reply was 'To change the world, darling. That's why.

And Virago did change the world, especially for women and for publishing. Pre-1970s, men made all the decisions about which books would be released into the world. Virago's mission was to bring in radical voices, to usher women writers in from the margins.

Maya Angelou was one such writer. Published in the US in 1969, I Know Why The Caged Bird Sings, the first volume of her memoir, had been rejected by many other publishers, saying no one would be

"The story of Virago is the history of feminism [...] [Maya Angelou's] first volume of her memoir, had been rejected by many other publishers, saying no one would be interested in the story of a young black girl growing up in the American South, before Virago accepted it in 1984.

interested in the story of a young black girl growing up in the American South, before Virago accepted it in 1984. Maya comes alive in the pages of Goodings' book; 'My mission in life is not merely to survive, but to thrive; and to do so with some passion, some compassion, some humour and some style.

One of the dictums of Virago was the Emily Dickinson's quote, 'Tell all the truth but tell it slant."1

By publishing stories of women's lives, Virago illuminated the cultural norms that were being challenged by the feminist movement. Goodings describes relishing the tension between radicalism and commercialism; between sisterhood and celebrity. From this tension sprang creativity and change. The story of Virago is the history of feminism.

The famous Virago classics were initially a way of connecting with a new audience. They set out to showcase female literary tradition and to challenge the notion of what a classic is. As Goodings says, 'Every writer stands on the shoulders of another writer', and the classics gently introduced women to feminist writing and thinking.

The range of authors published by Virago is extraordinary; Margaret Atwood, Sarah Waters, Marilynne Robinson, Naomi Wolf, Natasha Walter, Linda Grant, Sarah Dunant, and Sandi Toksvig among them.
Goodings really values and nurtures the relationship she has with her authors, and her respect and admiration for them is reciprocated. Her love of her work is palpable in her writing. As she said in one of the online book launch events (the publication of her book almost exactly coinciding with lockdown), We write best when we write about what's closest to our heart.' And writing, her authors, and Virago are clearly very close indeed to her heart.

Written by a woman who won a Lifetime Achievement Award at Women of the World, London's Southbank festival in 2018, and who has just been made a Fellow of the Royal Society of Literature, Bite of the Apple is part memoir, part feminist history, part history of Virago. As Margaret Atwood says on the cover, 'Delicious.

\section{Lesley Morrison,}

Retired GP, Scottish Borders.

Email: Lesleyjmorrison3Rgmail.com

DOI: https://doi.org/10.3399/bjgp21X714545

\section{REFERENCE}

. Dickinson E. Tell all the truth but tell it slant - (1263). 2020. https://www.poetryfoundation. org/poems/56824/tell-all-the-truth-but-tellit-slant-1263 (accessed 10 Dec 2020). 